\title{
Dissimilar patterns of tumor-infiltrating immune cells at the invasive tumor front and tumor center are associated with response to neoadjuvant chemotherapy in primary breast cancer
}

Lisa König ${ }^{1 *}$, Fabian D. Mairinger ${ }^{2}$, Oliver Hoffmann ${ }^{1}$, Ann-Kathrin Bittner ${ }^{1}$, Kurt W. Schmid ${ }^{2}$, Rainer Kimmig ${ }^{1}$, Sabine Kasimir-Bauer ${ }^{1+}$ and Agnes Bankfalvi ${ }^{2+}$

\begin{abstract}
Background: Tumor-infiltrating lymphocytes (TILS) are described as an important immune modulator in the tumor microenvironment and are associated with breast cancer (BC) outcome. The spatial analysis of TILs and TIL subtype distribution at the invasive tumor front (ITF) and the tumor center (TC) might provide further insights into tumor progression.

Methods: We analyzed core biopsies from 87 pre-therapeutic BC patients for total TILs and the following subtypes: CD3+, CD4+, CD8+, CD20+ and CD68+ cells in correlation to clinicopathological parameters and disseminated tumor cells (DTCs) in the bone marrow.

Results: TILs and TIL subtypes showed significantly different spatial distribution among both tumor areas. TILS, especially CD3+ T cells were associated with the tumor status and tumor grading. BC patients responding to neoadjuvant chemotherapy had significantly more TILs and CD3+ T cells at the TC. The presence of DTCs after NACT was related to CD4+ infiltration at the TC.

Conclusion: The dissimilar spatial association of TILs and TIL subtypes with clinicopathological parameters, NACT response and minimal residual disease underlines the necessity of detailed TIL analysis for a better understanding of immune modulatory processes.
\end{abstract}

Keywords: Breast cancer, Tumor-infiltrating lymphocytes, Tumor microenvironment, Neoadjuvant chemotherapy, Minimal residual disease, Disseminated tumor cells, T cells, B cells

\section{Background}

Breast cancer $(\mathrm{BC})$ is the most common malignant tumor and the second leading cause of cancer-related death in women worldwide [1]. Due to significant progress in early diagnosis and individualized treatment options, the clinical outcome of $\mathrm{BC}$ has improved in the recent decades [2]. The main goals of neoadjuvant chemotherapy

\footnotetext{
* Correspondence: Lisa.Koenig87@gmail.com

tSabine Kasimir-Bauer and Agnes Bankfalvi contributed equally to this work.

${ }^{1}$ Department of Gynecology and Obstetrics, University Hospital Essen,

University of Duisburg-Essen, Hufelandstr. 55, 45147 Essen, Germany

Full list of author information is available at the end of the article
}

(NACT) are the reduction of tumor burden and monitoring tumor response to NACT [3]. However, a pathological complete response (pCR) after NACT can be achieved in 46 to $60 \%$ of the patients and $20 \%$ experience a metastatic relapse [4-6]. This might be explained by micrometastatic spread of tumor cells, preferentially to the bone marrow (BM) as disseminated tumor cells (DTCs) [7, 8]. The presence and persistence of these cells as well as their prognostic relevance has widely been shown [9-14] which indicates a rationale for testing alternative or secondary treatment options. In this regard, some efforts, including

(c) The Author(s). 2019 Open Access This article is distributed under the terms of the Creative Commons Attribution 4.0 International License (http://creativecommons.org/licenses/by/4.0/), which permits unrestricted use, distribution, and reproduction in any medium, provided you give appropriate credit to the original author(s) and the source, provide a link to the Creative Commons license, and indicate if changes were made. The Creative Commons Public Domain Dedication waiver (http://creativecommons.org/publicdomain/zero/1.0/) applies to the data made available in this article, unless otherwise stated. 
chemo-, antibody- or bisphosphonate therapy, have already been published [15-20].

There is evidence that inflammatory mediators released by cancer cells and tumor-infiltrating lymphocytes foster the development of a tumor microenvironment (TME) favoring tumor proliferation, migration, invasion as well as epithelial-mesenchymal transition (EMT) [21, 22]. Therefore, the composition and balance of anti- and pro-tumorigenic immune cells interspersing malignant tissue play a critical role for disease outcome [23]. Tumor-infiltrating immune cells are frequently observed in cancer, but the immune cell subtype composition differs among tumor entities [24]. The association of increased TILs with favorable prognosis in BC is widely accepted, however the role of different TIL subtypes remains controversial [25]. The predictive and prognostic significance of TILs was validated in large clinical studies, especially in triple negative (TNBC) and HER2 positive $\mathrm{BC}[26,27]$. Overall, a high density of TILs was described to be associated with a favorable outcome in NACT treated $\mathrm{BC}$ patients. However, subgroup analysis according to different molecular $\mathrm{BC}$ subtypes reported a correlation between high TILs, a poor outcome but a higher $\mathrm{pCR}$ rate $[28,29]$. In a T cell subtype analysis, high levels of infiltrating CD8+ T cells were associated with a prolonged overall survival. CD4+ T helper cells were described to be a favorable prognostic factor with regard to overall clinical outcome [30,31], while the influence of immunosuppressive regulatory $\mathrm{CD} 4+\mathrm{T}$ cells still remains controversially debated [32-35]. B cells have been less extensively investigated, but are described to be associated with favorable disease outcome [36]. CD68+ macrophages were associated with worse prognostic features $[37,38]$ as well as shortened disease-free survival [38-40].

The crosstalk of tumor and immune cells located at the invasive tumor front (ITF) with the cells from the TME is essential for tumor progression and metastasis development $[41,42]$. It has been demonstrated first in colorectal cancer (CRC) that CD3+ and CD8+ lymphocytes are spatially differentially distributed between the tumor center (TC) and the ITF and that the density and pattern of these immune infiltrates were associated with CRC patient outcome [43]. This led to the development of the so called Immunoscore assay to qualify and quantify the local host immune reaction to cancer cells, based on the numeration of two lymphocyte populations (CD3+ T cells and CD8+ cytotoxic T cells), both in the core of the tumor (TC) and in the invasive margin.

To the best of our knowledge, this is the first study analyzing the clinical impact of differential spatial distribution of TILs in primary BCs at baseline from NACT-treated patients in correlation to prognostic and predictive parameters as well as minimal residual disease. Here we evaluated densities and infiltration patterns of TILs and TIL subtypes separately in the TC and at the ITF from 87 pre-NACT BC core biopsies and correlated these findings to i) clinicopathological parameters, ii) response to NACT and iii) DTC status in the BM pre- and post-therapy.

\section{Material and methods \\ Study design, patient and tumor characteristics}

This retrospective, single-center study comprises 87 women with histologically proven primary invasive, non-metastatic $\mathrm{BC}$ who were diagnosed and treated between 2009 and 2012 at the Department for Gynecology and Obstetrics and the Institute of Pathology of the University Hospital Essen, Germany. Further eligibility criteria included: availability of bone marrow samples for DTCs at baseline and post-NACT, no severe co-morbidities, no further malignancies and surgical therapy after NACT with postoperative evaluation of the pathological response. Treatment decisions and follow-up were in accordance with international recommendations included in the German guidelines at that time. Indication for and composition of NACT regimens were described in detail previously [13]. The clinical response to NACT was graded on a three-tier scale as i) no change (pNC), ii) partial remission (pPR) and iii) pathologic complete remission (pCR) with no residual invasive or noninvasive tumor cells in breast and lymph nodes (ypT0,ypTis0, ypN0) [44]. Tumor type and stage were assessed according to the WHO-Classification of malignant tumors of the breast [45] and the sixth edition of the TNM Classification System [46]. The histopathological tumor grading pre-treatment was performed according to the Nottingham system elaborated by Elston and Ellis [47]. The histological regression grade post-NACT was determined using the four-tier classification of Sinn et al. [48]. Patient and tumor characteristics are listed in Table 1. All patients gave written informed consent for use of their tumor tissue for research purposes. The study was approved by the institutional ethics committee (16-6915-BO) and fully conforms to the principles outlined in the declaration of Helsinki.

\section{Collection and analysis of DTCs from the bone marrow}

$\mathrm{BM}$ was aspirated from the anterior iliac crests from $\mathrm{BC}$ patients prior to and after completing NACT (pre-NACT: $n=61$, post-NACT: $n=72$, matched samples: $n=47$ ). All samples were obtained after written informed consent and collected using protocols approved by the institutional review board (05/2856). Isolation and detection of DTCs was performed according to current guidelines [49] and were described in detail elsewhere [13].

\section{Pathology assessment and immunohistochemistry}

Routinely formalin-fixed and paraffin-embedded (FFPE) pre-NACT core biopsies were retrieved from the 
Table 1 Patient and tumor characteristics

\begin{tabular}{|c|c|}
\hline Total & 87 \\
\hline Age & 53 years (range: $28-83$ ) \\
\hline \multicolumn{2}{|l|}{ Menopausal status } \\
\hline pre-menopausal & $43(50 \%)$ \\
\hline peri-menopausal & $6(7 \%)$ \\
\hline post-menopausal & $38(44 \%)$ \\
\hline \multicolumn{2}{|l|}{ T stadium pre-NACT } \\
\hline cT1a-cT1c & $20(23 \%)$ \\
\hline cT2 & $51(59 \%)$ \\
\hline$>c T 2$ & $14(16 \%)$ \\
\hline Unknown & $2(2 \%)$ \\
\hline \multicolumn{2}{|l|}{ T stadium post-NACT } \\
\hline ypT0, ypTis & $18(21 \%)$ \\
\hline ypT1a & $11(13 \%)$ \\
\hline урT1b, урT1с & $18(21 \%)$ \\
\hline ypT2 & $26(30 \%)$ \\
\hline >ypT2 & $10(12 \%)$ \\
\hline Unknown & $4(5 \%)$ \\
\hline \multicolumn{2}{|l|}{$\mathrm{N}$ stadium pre-NACT } \\
\hline cNO & $41(47 \%)$ \\
\hline $\mathrm{cN} 1$ & $40(46 \%)$ \\
\hline $\mathrm{cN} 2, \mathrm{cN} 3$ & $5(6 \%)$ \\
\hline Unknown & $1(1 \%)$ \\
\hline \multicolumn{2}{|l|}{$\mathrm{N}$ stadium post-NACT } \\
\hline yNo & $47(54 \%)$ \\
\hline yN1 & $29(33 \%)$ \\
\hline yN2/N3 & $8(9 \%)$ \\
\hline Unknown & $3(4 \%)$ \\
\hline \multicolumn{2}{|l|}{ Tumor type } \\
\hline Ductal invasive & $60(69 \%)$ \\
\hline Lobular invasive & $11(13 \%)$ \\
\hline Other & $14(16 \%)$ \\
\hline Unknown & $2(2 \%)$ \\
\hline \multicolumn{2}{|l|}{ Tumor grade } \\
\hline G1 & $4(5 \%)$ \\
\hline G2 & $40(46 \%)$ \\
\hline G3 & $42(48 \%)$ \\
\hline Unknown & $1(1 \%)$ \\
\hline \multicolumn{2}{|c|}{ Estrogen receptor $(\mathrm{IHC})^{\mathrm{a}}$} \\
\hline Positive & $68(78 \%)$ \\
\hline Negative & $19(22 \%)$ \\
\hline \multicolumn{2}{|c|}{ Progesterone receptor $(\mathrm{IHC})^{\mathrm{a}}$} \\
\hline Positive & $58(67 \%)$ \\
\hline Negative & $29(33 \%)$ \\
\hline
\end{tabular}

Table 1 Patient and tumor characteristics (Continued)

HER2 ${ }^{\mathrm{a}}$

$\begin{array}{ll}\text { Positive } & 23(26 \%) \\ \text { Negative } & 64(74 \%)\end{array}$

Tumor subtype

ER-, PR-, HER2-

$14(16 \%)$

ER-, PR-, HER2+

$4(5 \%)$

$E R+/ P R+, H E R 2-$

$50(58 \%)$

ER+, PR+, HER2+

$19(22 \%)$

NACT regimen

CTX

$53(61 \%)$

$C T X+$ Trastuzumab

$14(16 \%)$

$C T X+$ Avastin

$4(5 \%)$

CTX + Lapatinib + Trastuzumab

$6(7 \%)$

HTX

$9(10 \%)$

Unknown

$1(1 \%)$

Trastuzumab treatment

Yes

$20(23 \%)$

No

$66(76 \%)$

Unknown

$1(1 \%)$

Clinical response

$\begin{array}{ll}\text { PCR } & 15(17 \%) \\ \text { pPR } & 62(71 \%) \\ \text { pNC } & 6(7 \%) \\ \text { Unknown } & 4(5 \%)\end{array}$

Histological tumor regression grade ${ }^{b}$

$\begin{array}{ll}0 & 6(7 \%) \\ 1 & 32(37 \%) \\ 2 & 22(25 \%) \\ 3 & 5(6 \%) \\ 4 & 12(14 \%) \\ \text { Unknown } & 10(12 \%) \\ \text { Local treatment } & \\ \text { Mastectomy } & 56(64 \%) \\ \text { Breast conservation surgery } & 26(30 \%) \\ \text { Unknown } & 5(6 \%) \\ \text { DTC positive } & \\ \text { pre-NACT } & 16(18 \%) \\ \text { post-NACT } & 13(15 \%)\end{array}$

Positive ER and PR status (ER+, PR+) was defined based on the guidelines of the American Society of Clinical Oncology [88] and concordant German recommendations at that time. Accordingly, we used a cut off value of $1 \%$ for ER and PR status. Breast cancers were defined as HER2-positive (HER2+) only for those cases that were +3 by immunohistochemistry (IHC) (cut off 30\%) or +2 on IHC and confirmed positive by CISH [89]. Respective results were not re-defined because they served as a basis for therapy decision at baseline $\mathrm{b}_{[48]}$ 
archives of the Institute of Pathology. An average number of 5 biopsies (range: 1 to 20) were procured per BC patient with a median size of 0.6 to $1.5 \mathrm{~cm}$. Based on the availability of sufficient remaining tissue, core biopsies obtained before NACT were pre-screened on hematoxylin and eosin stained (H\&E) sections for the presence of at least $30 \%$ tumor tissue and representative areas of TC and ITF within the biopsy. The TC was defined as intra-tumoral areas comprising malignant epithelial glands and desmoplastic tumor stroma with no direct connection to the peri-tumoral non-tumorus breast tissue. The ITF was restricted to a narrow band-like area at the tumor/host interface with a width of approximately $1 \mathrm{~mm}$ between the invasive edge of carcinoma tissue and the adjacent non-tumorus fibro-adipose stroma of the mammary gland [50]. The finally stained samples contained in average three biopsies (range: 1 to 4) per slide. In detail, one biopsy was on the slide in 10 cases, two biopsies in 34 cases, three biopsies in 37 cases and four biopsies in six cases. One slide per TIL subtype per patient (in total 6 slides per patients to evaluate) was stained as follows. Two $\mu \mathrm{m}$ thick serial tissue sections were cut and mounted on SuperFrost $^{\circ}$ Plus slides (Menzel, Braunschweig, Germany) for IHC. After deparaffinization and antigen retrieval $\left(95^{\circ} \mathrm{C}\right.$; 20 min citrate buffer), IHC was performed using the automated staining system BenchMark Ultra (Ventana Medical Systems, Tucson, USA) according to the manufacturer's instruction. Staining was performed simultaneously on all slides with each antibody to avoid intersection variability. The following primary antibodies were used: CD3 (clone: SP7, DCS Innovative DiagnostikSysteme, Hamburg, Germany; dilution: 1:400), CD4 (clone: 1F6, Zytomed Systems, Berlin, Germany; dilution: 1:40), CD8 (clone: C8/144B, DAKOCytomation, Glostrup, Denmark; dilution: 1:150), CD20 (clone: L26, DAKOCytomation, Glostrup, Denmark; ready to use), CD68 (clone: PG-M1, DAKOCytomation, Glostrup, Denmark; dilution: 1:500). Visualization of primary antibody binding was enabled using the OptiView DAB detection kit (Ventana Medical Systems, Tucson, USA). Positivity was defined by membranous staining of immune cells, irrespectively of the staining intensity. Human tonsil tissue sections served as routine positive control in each run and the staining quality was verified by the study breast pathologist.

\section{Assessment of tumor-infiltrating immune cells}

One biopsy per patient was semi-quantitatively evaluated using a light microscope (Axioskop 2, Zeiss, Oberkochen, Germany) at 100x. The densities of the total TILs (H\&E) and IHC-determined TIL subtypes were evaluated separately in the TC and at the ITF in the core biopsies, based on the recommendations of the International TILs Working Group and adapted with some practical modifications $[23,51]$. Scores were defined as the percent proportion of the area infiltrated by the immune cells in the TC and at the ITF according to recommendations of Denkert et al. [28] and Salgado et al. [52], irrespective of intraepithelial or stromal localization. The quantity of TILs infiltration was classified into three categories: low $(\mathrm{L})=0-10 \%$, moderate $(\mathrm{M})=11-30 \%$ and high $(\mathrm{H}) \geq 31 \%$ infiltration. For binary statistics, low infiltrations were defined as "TIL-poor", while moderate and high TILs were combined into "TIL-rich" categories.

In accordance with the Immunoscore (IS)-concept of Galon et al. [43, 53], two-marker immune profile estimations were also performed in situ by assessing the relative density of $\mathrm{CD} 3+/ \mathrm{CD} 8+, \mathrm{CD} 4+/ \mathrm{CD} 8+, \mathrm{CD} 68+/ \mathrm{CD} 8$ + , CD3+/CD20+ and CD68+/CD20+ immune cell populations in the TC and ITF regions [38, 54]. The dual scores were graded as follows: IS-G1 [high densities of both markers in both localizations $(4 \mathrm{xH})]$, IS-G2 [heterogeneous densities $(3 \mathrm{xH}, 2 \mathrm{xH}, 1 \mathrm{xH})$ for both markers and localizations] and IS-G3 [low densities of both markers at both areas (4xL) [55].

To minimize intra-observer variability, each staining was analyzed twice: (i) all slides from one immune cell subtype staining, (ii) all stained slides from one patient. The results were randomly re-checked by the study pathologist. A good inter-observer agreement was found $(\kappa=0,767)$. Figure 1 shows representative $H \& E$ staining (A) as well as CD3 IHC (B) for each infiltration category and for both tumor areas. IHC staining images for CD4, CD8, CD20 and CD68 are provided as supplementary material (Additional file 1: Figure S1).

\section{Statistical analysis}

All statistical analyses were calculated using the R i386 statistical programming environment (v3.2.3). Before starting the literal statistical analysis, the ShapiroWilks-test was applied to test for normal distribution of the data. Subsequently, either a parametric or non-parametric test was applied. For dichotomous variables either the Wilcoxon Mann-Whitney rank sum test (non-parametric) or two-sided student's t-test (parametric) was utilized. For ordinal variables with more than two groups, either the Kruskal-Wallis test (non-parametric) or ANOVA (parametric) was used to detect group differences. Double dichotomous contingency tables were analyzed using Fisher's exact test. To test dependence to ranked parameters with more than two groups the Pearson's Chi-squared test was applied. Correlations between metric or pseudometric parameters were tested by using the Pearson's product moment correlation test for linear and the Spearman's rank correlation test for non-linear regression, respectively. Due to the multiple statistical tests the $p$-values were adjusted by calculating the false discovery rate (FDR). Minimal sample size for each 


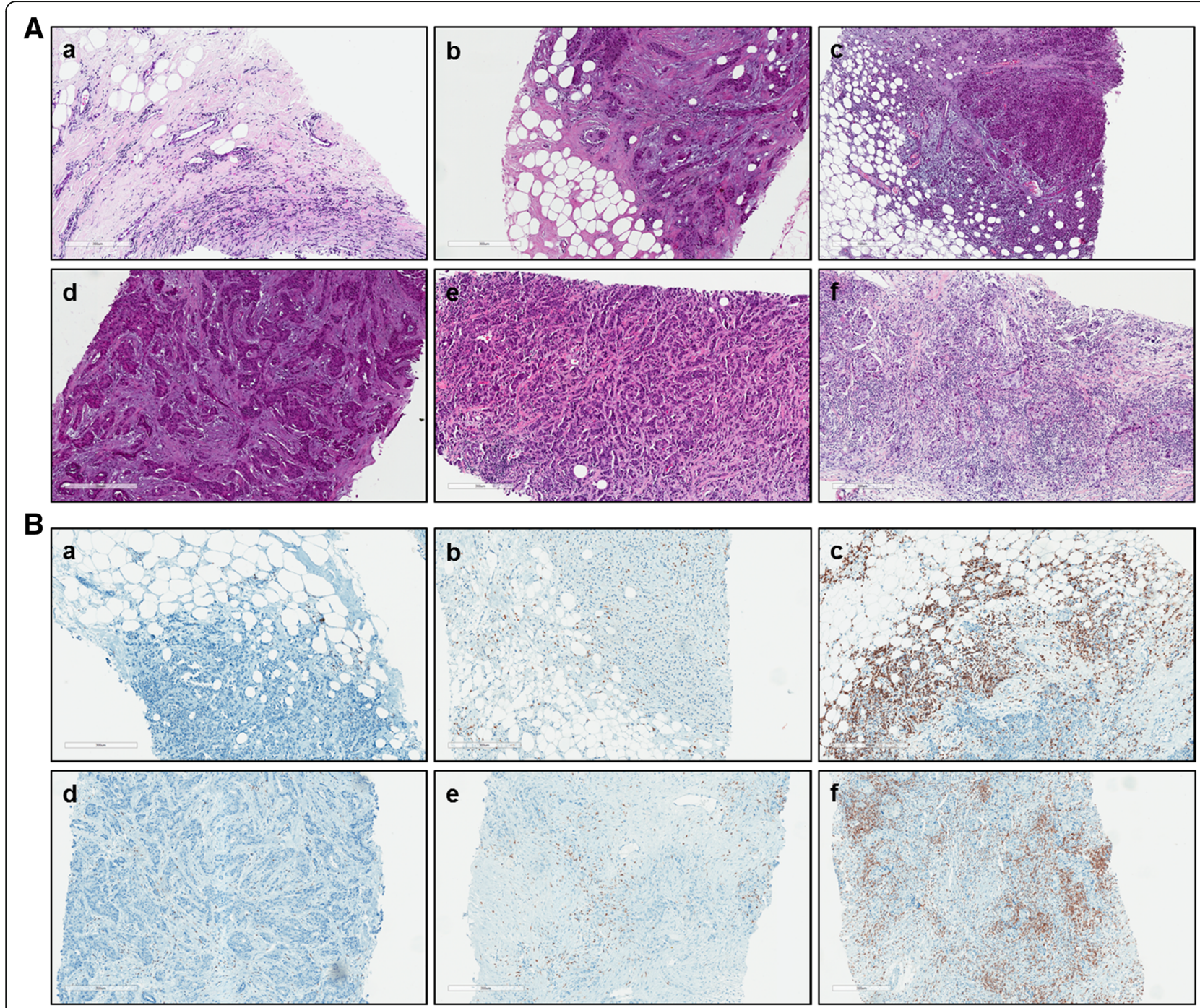

Fig. 1 Representative H\&E and immunohistochemistry (IHC) staining. Images show represenative H\&E (A) and IHC staining for CD3 (B) at the ITF $(\mathbf{a}-\mathbf{c})$ and in the TC $(\mathbf{d}-\mathbf{f})$ for each category $(\mathbf{a} / \mathbf{d}=$ Low, $\mathbf{b} / \mathbf{e}=$ Moderate, $\mathbf{c} / \mathbf{f}=$ High $)$

distinct group has been calculated using power calculation with Type I error probability of 0.05 and Type II error probability of 0.1 . On a basis of a two-sample, two-sided $\mathrm{t}$-test $(\mathrm{SD}=1$, delta $=1)$, the minimal sample size has been calculated as 23 . The level of statistical significance was defined as $p \leq 0.05$ after adjustment.

\section{Results}

\section{Frequency distribution of total TILs and immune cell} subtypes in pre-NACT core biopsies

In total, $73(84 \%)$ of the 87 tumors studied were infiltrated by TILs. The dominant TILs subtype across all BCs included $\mathrm{CD} 3+\mathrm{T}$ lymphocytes, which were detected in 64 (74\%) tumors, followed by CD8+ T cells in 59 (68\%) and $\mathrm{CD} 20+\mathrm{B}$ cells in $57(66 \%)$ of the cases. Half of the tumors (50\%) were infiltrated by CD68+ macrophages and 27 (31\%) BCs had a CD4+ T cell infiltration (Fig. 2).
Differential density distribution of total TILs and TIL subtypes at the ITF and in the TC

At the ITF, the majority of the tumors $[n=69,(80 \%)]$ were infiltrated at high and moderate levels by TILs. Regarding the quantity of infiltration by different cell types, high and moderate subtype density was observed most frequently for CD3+ lymphocytes $[n=60,(69 \%)$, followed by CD20+ B cells in $55(63 \%)$ and CD8+ lymphocytes in 48 cases (55\%). CD68+ macrophages and $\mathrm{CD} 4+\mathrm{T}$ cells were mainly present in low concentrations or lacked completely (Fig. 2a).

The TC was predominantly moderately infiltrated by TILs $[n=42,(48 \%)]$ and $27(31 \%)$ of the tumors showed low level infiltration or were completely negative for TILs. 18 tumors (21\%) were highly infiltrated by total TILs at the TC. CD3+ T cells represented the predominant subtype with high and moderate infiltration of the 

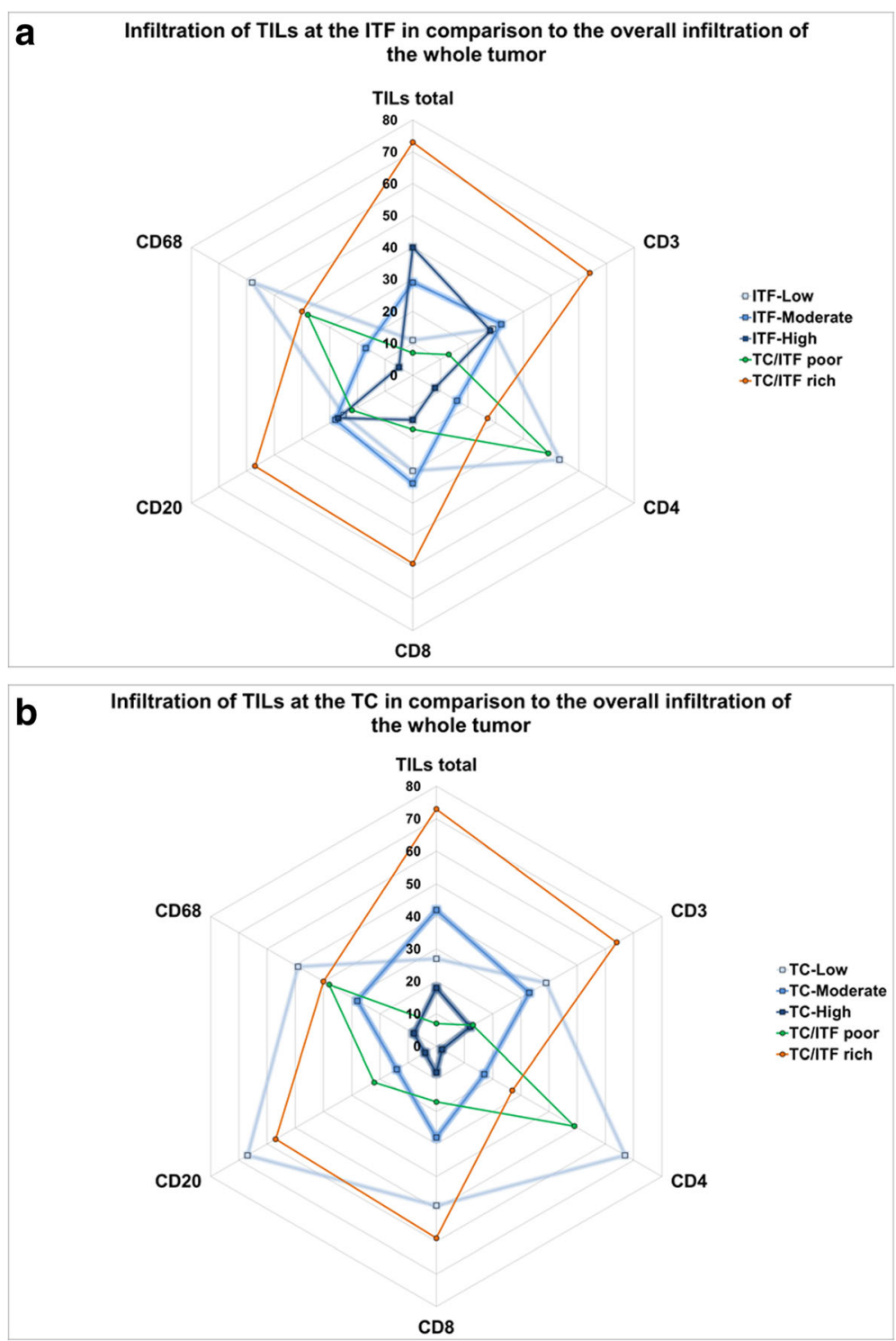

Fig. 2 Distribution of TILs and TIL subtypes through the whole tumor. These radar plots show the number of breast carcinomas being infiltrated by the different TIL infiltration categories. TIL-poor tumors were defined as BCs with low level infiltration or complete lack of TILs both at the ITF and in the TC. TIL-rich tumors had a moderate or high level of immune cell infiltration at both intratumoral areas. a High levels of total TILs were mainly observed at the ITF, whereas the TC contained generally less immune cells. The ITF was most frequently interspearsed with CD3+ T lymphocytes, CD20+ B cells and CD8+ T cells. CD68+ macrophages and and CD4+ T cells cells were found in lower amounts at the ITF. $\mathbf{b}$ In the TC, CD3+ T cells were found to be the prevalent subtype, whereas low amounts of CD20+, CD68+, CD4+ and CD8+ cells were present, or there was no immune infiltration in the TC at all. The TIL infiltration is depicted by the number of tumors showing the certain infiltration densities

TC in 45 tumors (52\%), while all other TIL subtypes were mainly present in low levels or lacked completely (Fig. 2b).

Interrelationship between TILs and TIL subtype infiltration at the ITF and in the TC

Both intratumoral localizations showed a significant positive correlation between total TILs and immune cell subtype infiltrations. However, the composition of the immune cell infiltrate was significantly different in the two regions. At the ITF, the amount of total TILs was positively associated with all TIL subtypes, except CD68 + macrophages. In particular, the presence of $\mathrm{CD} 3+\mathrm{T}$ cells was significantly correlated with $\mathrm{CD} 4+$ and $\mathrm{CD} 8+$ $\mathrm{T}$ lymphocytes $(p=5.35 \mathrm{E}-5$ and $p=0.0054)$ as well as with CD20+ B cell infiltrations $(p=1.39 \mathrm{E}-5)$. The presence of $\mathrm{CD} 20+\mathrm{B}$ cells was significantly related to infiltration with $\mathrm{CD} 3+\mathrm{T}$ cells and $\mathrm{CD} 8+\mathrm{T}$ lymphocytes $(p=1.39 \mathrm{E}-5$ and $p=0.0178)$. An additional association between CD8+ and CD4+ T cells was found ( $p=0.0112)$. 
CD68+ macrophages were not associated with any TIL subgroup at the ITF (Table 2A).

In the TC, total TILs and TIL subtypes were related to each other in a similar manner with some differences. Remarkably, CD68+ macrophages were here significantly associated with total TILs infiltration $(p=0.0011)$, whereas no correlation with $\mathrm{T}$ cell subtypes and $\mathrm{B}$ lymphocytes was found (Table 2B). Furthermore, CD $8+T$ cells were not associated with CD4+ T cells in the TC.

The comparison of total TIL infiltration between the two areas revealed, if more total TILs were infiltrating the ITF, more were present in the TC and vice versa $(p$ $=0.0005$ ). Similarly, highly significant correlations were observed for CD3+ T cells $(p=0.0005), \mathrm{CD} 4+\mathrm{T}$ cells $(p=0.0012)$ and CD68+ macrophages $(p=0.0026)$ between the infiltration densities in the two different regions. The combined analysis of TC and ITF demonstrated a high proportion of total TILs in the TC significantly related to an elevated infiltration of $\mathrm{CD} 3+$ and CD4+ T cells $(p=0.0003$ and $p=0.0023)$, as well as to $\mathrm{CD} 20+\mathrm{B}$ cells at the ITF $(p=0.0251)$. A high amount of $\mathrm{CD} 3+$ cells at the TC was significantly related to high infiltrates of CD3+ $(\mathrm{p}=0.0005)$, total TILs $(p=0.0013), \mathrm{CD} 4+(p=0.0011), \mathrm{CD} 20+(p=0.0013)$ and CD8+ cells $(p=0.0086)$ at the ITF. CD20+ B cells as well as $\mathrm{CD} 8+\mathrm{T}$ lymphocytes differed between the two regions (Table $2 \mathrm{C}$ ).

Overall, the composition of the immune infiltration was significantly different between the TC and the ITF regions. There was a highly significant accumulation of total TILs ( $p=6.666 \mathrm{E}-7)$ and all immune subsets at the ITF. Of note, CD20+ B cells were predominant at the ITF compared to the TC $(p=2.299$ E-11). Higher densities of the $\mathrm{T}$ cell subsets with main subtypes of $\mathrm{CD} 3+(p=1.109 \mathrm{E}-6), \mathrm{CD} 8+(p=0.0031)$ and $\mathrm{CD} 4+\mathrm{T}$ cells $(p=0.0073)$ were also present at the ITF. The difference for CD68+ macrophages was less significant $(p=0.0103)$ (data not shown).

Table 2 Correlation between TIL subtype infiltration at the TC and the ITF

A: Correlation TILs ITF-ITF

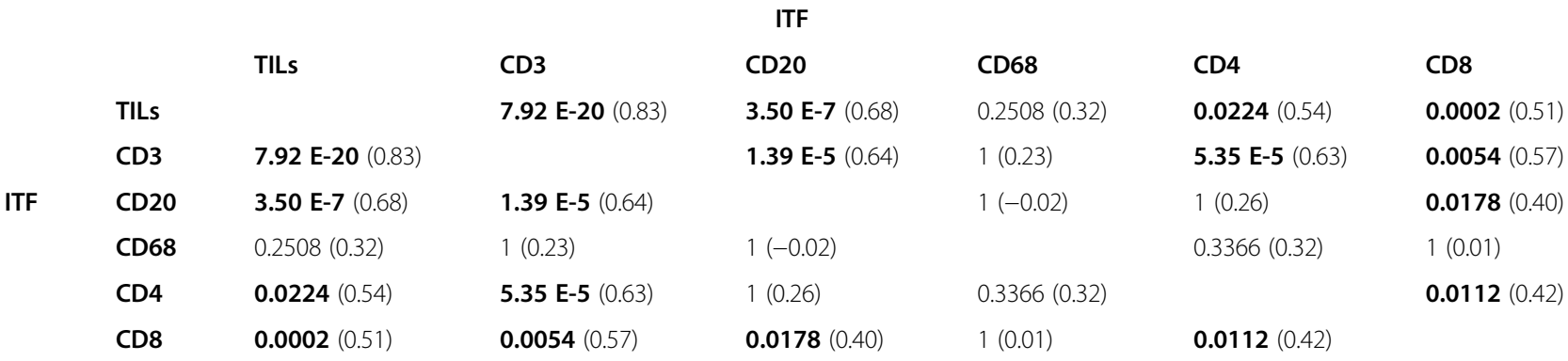

B: Correlation TILs TC-TC

\begin{tabular}{|c|c|c|c|c|c|c|c|}
\hline \multicolumn{8}{|c|}{$C$} \\
\hline \multirow{6}{*}{ TC } & \multirow[b]{2}{*}{ TILs } & \multirow[t]{2}{*}{ TILs } & \multirow{2}{*}{$\begin{array}{l}\text { CD3 } \\
6.6 \text { E-17 (0.78) }\end{array}$} & \multirow{2}{*}{$\begin{array}{l}\text { CD20 } \\
\mathbf{0 . 0 0 1 8}(0.44)\end{array}$} & \multirow{2}{*}{$\begin{array}{l}\text { CD68 } \\
\mathbf{0 . 0 0 1 1}(0.45)\end{array}$} & CD4 & \multirow{2}{*}{$\begin{array}{l}\text { CD8 } \\
5.08 \text { E-5 }(0.61)\end{array}$} \\
\hline & & & & & & $0.0086(0.4)$ & \\
\hline & CD3 & $6.6 \mathrm{E}-17(0.78)$ & & 7.26 E-5 $(0.5)$ & $1(0.1)$ & $\mathbf{0 . 0 2 9 0}(0.37)$ & 2.05 E-7 (0.67) \\
\hline & CD20 & $0.0018(0.44)$ & 7.26 E-5 (0.5) & & $1(-0.02)$ & $1(0.21)$ & $\mathbf{0 . 0 0 5 1}(0.55)$ \\
\hline & CD68 & $\mathbf{0 . 0 0 1 1}(0.45)$ & $1(0.1)$ & $1(-0.02)$ & & $0.099(0.34)$ & $1(0.1)$ \\
\hline & CD4 & $0.0086(0.4)$ & $\mathbf{0 . 0 2 9 0}(0.37)$ & $1(0.21)$ & $0.099(0.34)$ & & $0.0568(0.36)$ \\
\hline & CD8 & 5.08 E-5 $(0.61)$ & 2.05 E-7 (0.67) & $\mathbf{0 . 0 0 5 1}(0.55)$ & $1(0.1)$ & $0.0568(0.36)$ & \\
\hline \multicolumn{8}{|c|}{ C: Correlation TILs ITF-TC } \\
\hline & & & & ITF & & & \\
\hline & & TILs & $\mathrm{CD} 3$ & CD20 & CD68 & CD4 & CD8 \\
\hline & TILs & $0.0005(0.48)$ & $\mathbf{0 . 0 0 0 3}(0.49)$ & $\mathbf{0 . 0 2 5 1}(0.39)$ & $0.924(0.27)$ & $\mathbf{0 . 0 0 2 3}(0.45)$ & $0.1254(0.35)$ \\
\hline & $\mathrm{CD} 3$ & $\mathbf{0 . 0 0 1 3}(0.46)$ & $\mathbf{0 . 0 0 0 5}(0.49)$ & $0.0013(0.46)$ & $1(0.08)$ & $0.0011(0.48)$ & $\mathbf{0 . 0 0 8 6}(0.42)$ \\
\hline \multirow[t]{4}{*}{ TC } & CD20 & $1(0.12)$ & $1(0.08)$ & $1(0.23)$ & $1(-0.19)$ & $1(0.08)$ & $1(0.08)$ \\
\hline & CD68 & $1(0.22)$ & $1(0.23)$ & $1(0.03)$ & $\mathbf{0 . 0 0 2 6}(0.45)$ & $0.0653(0.37)$ & $1(0.03)$ \\
\hline & CD4 & $1(0.1)$ & $1(0.16)$ & $1(0.05)$ & $1(0.25)$ & $\mathbf{0 . 0 0 1 2}(0.47)$ & $1(0.12)$ \\
\hline & CD8 & $1(0.2)$ & $1(0.24)$ & $0.495(0.30)$ & $1(-0.09)$ & $1(0.21)$ & $1(0.2)$ \\
\hline
\end{tabular}

Bonferroni adjusted p-values (rho)

(A) ITF-ITF, (B) TC-TC and (C) ITF-TC. Results are given as Bonferroni adjusted p-values (rho). All bold values are significant p-values with "rho" in brackets 
Association of TILs and TIL subtypes at the ITF and in the TC with clinicopathological parameters

Among the clinicopathological characteristics examined (Table 1), only tumor grade and tumor size pre- and post NACT were significantly associated with immune infiltrates in the pre-treatment core biopsies. The tumor grade was directly correlated with the degree of total TILs and CD3+ $\mathrm{T}$ cell infiltrations. Less differentiated tumors had significantly higher levels of TILs at both tumor areas $(p=0.047$, respectively) and increased amount of CD3+ T cells at the ITF $(p=0.0407)$ (Table 3$)$. Tumor size pre-NACT (cT-stage) was inversely correlated with the density of total TILs, CD3+ T cells and CD4+ $\mathrm{T}$ lymphocytes in the $\mathrm{TC}$; they were highly

Table 3 Association of TILs and TIL subtypes with clinicopathological characteristics

\begin{tabular}{|c|c|c|c|}
\hline \multirow[b]{2}{*}{ Clinical parameter } & \multirow[b]{2}{*}{ TIL subtype } & \multicolumn{2}{|l|}{$p$-value } \\
\hline & & ITF & $\mathrm{TC}$ \\
\hline \multirow[t]{2}{*}{ Tumor grade } & TILS & $0.047^{a}$ & $0.047^{a}$ \\
\hline & CD3 & $0.0407^{\mathrm{a}}$ & \\
\hline \multirow[t]{3}{*}{ CT stadium (pre-NACT) } & TILs & & $0.004^{d}$ \\
\hline & CD3 & & $0.004^{d}$ \\
\hline & CD4 & & $0.0118^{b}$ \\
\hline \multirow[t]{7}{*}{ ypT stadium (post-NACT) } & TILs & $0.0069^{c}$ & $0.0014^{c}$ \\
\hline & CD3 & $0.0010^{c}$ & $0.0069^{c}$ \\
\hline & CD4 & $0.0014^{c}$ & \\
\hline & $\mathrm{CD} 8$ & $0.0197^{c}$ & \\
\hline & $\mathrm{CD} 20$ & $0.0151^{c}$ & \\
\hline & IS CD3/CD8 & $0.0254^{c}$ & \\
\hline & IS CD3/CD20 & $0.0144^{c}$ & \\
\hline \multirow[t]{2}{*}{ clinical response } & TILS & & $0.0204^{b}$ \\
\hline & CD3 & & $0.0235^{b}$ \\
\hline \multirow[t]{7}{*}{ histological regression grade } & TILs & & $0.0007^{c}$ \\
\hline & CD3 & $0.0308^{c}$ & $0.0002^{c}$ \\
\hline & CD4 & $0.037^{c}$ & \\
\hline & CD8 & $0.0308^{c}$ & $0.0008^{c}$ \\
\hline & CD20 & $0.023^{c}$ & $0.0196^{c}$ \\
\hline & IS CD3/CD8 & $0.0093^{c}$ & \\
\hline & IS CD3/CD20 & $0.0481^{c}$ & \\
\hline DTC presence post-NACT & CD4 & & $0.0296^{c}$ \\
\hline
\end{tabular}

High amounts of total TILs and CD3+ T cells at the ITF were associated with smaller tumor sizes post-NACT. Comparable results were observed for both immune infiltrates in the TC. The tumor grading was directly correlated with the amount of total TILs both at the ITF and in the TC as well as with the level of $\mathrm{CD} 3+$ cells at the ITF. Favourable NACT responses, evaluated by pathological response rate and histological regression grade, were directly associated with significantly higher amounts of total TILs and CD3+ cells present in the TC. Elevated amounts of CD4+ cells in the TC were associated with DTC presence post-NACT

${ }^{\mathrm{a} L M}$

${ }^{\mathrm{b}}$ Kruskal-Wallis test

'Spearman

${ }^{\mathrm{d}}$ Wilcoxon rank sum test present at early stages (cT1) and then decreased along with tumor progression $(p=0.004$ for total TILs and CD3+ and $p=0.011$ for CD4+ T cells). Tumor size post-NACT (ypT-stage) showed an inverse correlation with the degree of total TILs infiltration at the ITF $(p=0.0069)$ and in the TC $(p=0.0014)$ as well as with CD3+ T cells at the ITF $(p=0.001)$ and at the TC $(\mathrm{p}=0.0069)$. Likewise, high levels of CD4+ and CD8+ T cells as well as CD20+ B cells at the ITF were significantly related to smaller tumors post-NACT (Table 3). An inverse correlation between post-NACT tumor stage and the grade of the Immunoscore-like dual marker combinations of CD3/ CD8 and CD3/CD20 ( $p=0.0254$ and $p=0.0144)$ were observed, indicating that higher level infiltration of $\mathrm{CD} 3+\mathrm{T}$ cells either with CD8+ T cells or with CD20+ B cells in both tumor regions was associated with a reduced tumor size after therapy.

\section{Association of TILs and TIL subtypes at the ITF and in the TC with response to NACT}

Response to NACT was primarily evaluated with regard to the pathological response rate (pCR) and secondly to the histological regression grade [48]. An improved response rate to NACT was observed with increasing amounts of total TILs and CD3+ T cells in the TC $(p=0.0204$ and $p=0.0235)$ (Table 3$)$. Higher histological regression grades were significantly associated with increased total TILs in the TC $(p=0.0007)$ as well as with elevated levels of $\mathrm{CD} 3+$ and $\mathrm{CD} 8+\mathrm{T}$ lymphocytes and $\mathrm{CD} 20+\mathrm{B}$ cells at both intratumoral regions. CD4+ infiltrates were only associated with tumor shrinkage after therapy when localized at the ITF (Table 3). It is of note, that the IS-like dual marker combinations CD3/CD8 and $\mathrm{CD} 3 / \mathrm{CD} 20$ were directly related to the histological regression grade $(p=0.0093$ and $p=0.0481)$ post-NACT (Table 3). There were no significant associations between TILs and the different NACT regimens applied.

\section{Correlation of TILs with tumor cell dissemination into the bone marrow}

Overall, $19 \mathrm{BC}$ patients showed DTCs in the BM at one time point, while 28 patients did not have DTCs before and after NACT. In average, one DTC was present before (range: $1-14$ ) and after (range: $1-7$ ) NACT. While no association with DTC presence before NACT was found, the presence of DTCs post-NACT was significantly associated with a higher incidence of CD4+ T cells at the TC $(p=0.0296)$ (Table 3$)$.

\section{Discussion}

Understanding the cellular and molecular mechanisms of the tumor immune microenvironment is becoming increasingly important with the emerging role of immunotherapy in breast cancer [56]. 
In the present study, we confirmed that pre-treatment TIL infiltration pattern significantly differed between ITF and TC in primary BC.

In line with the most published studies, TIL infiltration was found in more than $80 \%$ of all tumors and the overall predominant TIL subtype included CD3+ T cells, with $\mathrm{CD} 8+\mathrm{T}$ cells being the main subset. The infiltration of CD4+ $\mathrm{T}$ cells was lower in our patient cohort than in the study of Garcia-Martinez et al. [54]. CD68+ macrophages were present in about the half of all tumors which is in concordance with other studies [54, 57]. The heterogeneous spatial distribution of TILs and TIL subtypes between the ITF and the TC has also been reported by Mani et al. [58]. Likewise, they found CD3+ $\mathrm{T}$ cells as the predominant TIL subtype in both tumor areas. Our finding of a significant accumulation of total TILs and all immune cell subtypes at the ITF provides evidence that the ITF represents an immunological hot spot area of communication between tumor and host. This phenomenon was also described for CRC [43, 55, 59] as well as in other solid tumors, including breast cancer [24, 38, 60, 61].

The positive correlation between total TILs and especially CD3+ T cells at the ITF and TC confirmed the observed TIL infiltration pattern with $\mathrm{T}$ cells as the dominant subtype while CD20+ B cells were predominantly located at the ITF. The concept of a time sequenced infiltration, $B$ cells following the primarily responding $\mathrm{T}$ cells, provides an explanation for the spatially different subtype presence [62].

The correlation between TILs and immune cell subtypes with regard to chemotherapy response and survival has been investigated in various studies $[25,28,35,63$, $64]$, but the association with clinicopathological parameters remains controversial [27, 28, 54, 65, 66]. Significantly higher TILs and CD3+ levels at the ITF in less differentiated tumors confirmed previous findings of others [66]. In contrast to other groups, we observed an association of smaller tumors post-NACT with a higher infiltration level of pre-treatment TILs and CD3+ cells at the ITF [66]. This may be explained by chemotherapy triggering or enhancing an anti-tumor immune response, thus, contributing to tumor remission [67].

Regarding the relationship between immune cell infiltration and clinicopathological patients' and tumor characteristics, we did not find any association with the hormone receptor status, $\mathrm{BC}$ subtypes and any other parameters tested, in contrast to other studies [27, 66]. These divergent results might be explained by our separate spatial analysis of total TILs and immune cell subtypes at the ITF and the TC, whereas all other groups assessed the entire tumor.

Enhanced TILs and CD3+ T cells levels were found to be associated with a higher rate of $\mathrm{pCR}$ in $\mathrm{BC}$ patients in several studies [25, 27, 28, 35, 54, 63]. Besides the significant role of $\mathrm{CD} 3+, \mathrm{CD} 8+$ and $\mathrm{CD} 20+$ lymphocytes at both intratumoral regions in $\mathrm{pCR}$, our results revealed that the infiltration of the TC with total TILs and CD3+ $\mathrm{T}$ cells was also significantly associated with NACT response and the pathological regression score [48] and was also described for entire tumor analyses in other neoadjuvant BC TIL studies [28, 29, 54, 63, 68]. Further, neoadjuvant $\mathrm{BC}$ trials investigating TNBC and HER2 positive BC subgroups [GeparQuattro [27], GeparQuinto [69], GeparSixto [70] and NeoALLTO [52] trials] confirmed this finding. This underlines again the clinical significance of the heterogeneous spatial distribution of TILs. In comparison to these trials we did not observe a relation of TILs to different NACT regimen [28, 69].

One of the novelties of the current study was the in situ analysis of different IS-like dual marker combinations. We demonstrated that higher $\mathrm{CD} 3 / \mathrm{CD} 8$ and $\mathrm{CD} 3 / \mathrm{CD} 20$ scores significantly correlated with advanced histological regression grades and reduced tumor size post-NACT. These findings support the central role of cytotoxic CD8+ T lymphocytes within the CD3+ T cell subset and the potential regulatory role of $\mathrm{CD} 20+\mathrm{B}$ lymphocytes on $\mathrm{T}$ cell function during tumor cell elimination [36].

The International TILs working group defined recommendations for TILs analysis and suggested the inclusion of the spatial differential analysis at TC and ITF $[23,51]$. The good inter-observer agreement in the present study was in line with others and proved this TIL evaluation method as independent from the observer [71, 72]. Commonly, TILs are analyzed from pre-NACT core biopsies or primary tumor tissue evaluating hematoxylin and eosin stained sections (H\&E) and TIL subtypes were assessed by using immunohistochemical staining or immune gene signatures [25]. It has been demonstrated that the TIL distribution in a single biopsy of a tumor is representative of the whole tumor [58]. We are aware of the limitations of our study, as we were retrospectively analyzing a small cohort of early primary breast carcinomas. Besides described BC specific eligibility criteria, the availability of DTC analysis was mandatory and the investigation of the correlation to TILs was a main aim in this study. However, these stringent study criteria did not allow a differentiated BC subgroup analysis, which was a primary aim in the BIG 02-98 and the FinHER trial. Currently, there is no standard TILs evaluation method defined and used throughout all studies, which might explain the diverse results between the huge numbers of studies.

To the best of our knowledge, we are the first group investigating DTCs, which reflect pre-treatment tumor cell dissemination into the $\mathrm{BM}$ and minimal residual disease after NACT, in correlation with the cellular immunity in the tumor microenvironment. The presence of 
DTCs after NACT was significantly associated with higher levels of $\mathrm{CD} 4+\mathrm{T}$ cells located in the TC pre-NACT. In this context, DeNardo et al. demonstrated metastatic spread into the lungs upon CD4+ T cells regulating pro-tumorigenic macrophage activity. However, a high $\mathrm{CD} 4+/ \mathrm{CD} 8+$ ratio was not related to tumor cell dissemination in our study [73]. Regulatory CD4+ T cells can prevent the differentiation and expansion of cytotoxic T cells as well as DC maturation [74-76] and therefore prevent tumor elimination. The initiation of the pre-metastatic niche, e.g. in the BM, can be realized by CD4+ Tregs as well [77]. Remarkably, the CD4+ T cells in the TC, but not at the ITF correlated with DTCs. This leads to the suggestion that tumor cell dissemination may not depend on a direct physical interaction at the tumor-host interface, but rather on a communication via secreted cytokines/chemokines. It is conceivable, that CD4+ T cells facilitate dissemination of tumor cells exhibiting stem-cell character or an EMT phenotype. For BC, DTCs with stem cell character have already been detected $[78,79]$ and the molecular characterization of circulating tumor cells in this patient cohort identified tumor cells with a stem-cell phenotype or in EMT after the completion of NACT [13]. However, although the prognostic significance of DTCs has been demonstrated in a variety of studies, not all patients with detectable DTCs have a higher risk of relapse. The group by Falck et al., could not confirm the negative prognostic impact of DTCs in a cohort of 401 primary BC patients [80]. On the one hand, this might be explained by the use of immunofluorescence for staining of DTCS which is not the standard method that has been recommended after a consensus discussion [49]. Immunofluorescence is critical because of BM auto-fluorescence and endogenous immune cell properties as well as BM matrix components that can generate false-positive staining results which has been demonstrated very recently [81]. On the other hand, not all of the detected DTCs have metastatic potential. Pantel and Hayes, 2018, proposed an interesting model postulating that only patients who harbor DTCs with stem cell character with full metastatic potential of self-renewal and immortality among all other tumor bulk cells will develop metastasis years after first diagnosis [82]. Thus, before using DTCs as a diagnostic tool, a more precise characterization of the cells is necessary to identify patients who might have a higher risk for relapse.

$\mathrm{BC}$ was considered a non-immunogenic tumor entity before analyzing TIL infiltration [83] At current, the application of T cell-mediated immunotherapy of CTLA-4 [84, 85] and PD-L1 inhibitors [86] in combination with standard of care BC therapy in $\mathrm{BC}$ patients is quite promising [87]. However, the possibility of offering immunotherapies to $\mathrm{BC}$ patients depends on the tumor infiltration by certain immune cells. Our results contribute to increasing the knowledge about the complex interactions between $\mathrm{BC}$ and its inflammatory microenvironment with putative prognostic and predictive value.

\section{Conclusions}

We demonstrated that dissimilar immune disposition at the ITF and TC is differentially associated with pro- and anti-tumor immunity, tumor cell dissemination and tumor response to contemporary NACT regimens in this cohort of early primary breast carcinomas. Further studies with comprehensive morpho-molecular evaluation of abundance, type and intra-tumoral location of tumor infiltrating immune cells might help to unravel their clinical relevance in the tumor immune microenvironment as well as their potential role as biomarker for or target of future treatment of breast cancer with personalized immuno therapies.

\section{Additional file}

Additional file 1: Figure S1. Representative immunohistochemistry (IHC) staining images for CD8, CD4, CD20 and CD68. Images show representative images for $\mathrm{CD} 8, \mathrm{CD} 4, \mathrm{CD} 20$ and CD68 at the ITF (a-c) and in the TC $(d-f)$ for each category $(a / d=L o w, b / e=$ Moderate, $c / f=H i g h)$. (TIF 2130 kb)

\section{Abbreviations \\ BC: Breast cancer; BM: Bone marrow; CD: Cluster of differentiation; CRC: Colorectal cancer; CTC: Circulating tumor cell; CTX: Chemotherapy; DTC: Disseminated tumor cell; ER: Estrogen receptor; FDR: False discovery rate; FFPE: Formalin-fixed paraffin-embedded; H: High; H\&E: Hematoxylin and eosin; HER2: Human epidermal growth factor receptor-2; HTX: Hormonal therapy; IHC: Immunohistochemistry; IS: Immunoscore; ITF: Invasive tumor front; L: Low; M: Moderate; NACT: Neoadjuvant chemotherapy; \\ pCR: Pathological complete response; pNC: No change; pPR: Partial response; PR: Progesterone receptor; TC: Tumor center; TIL: Tumor-infiltrating lymphocyte; TNBC: Triple negative breast cancer}

\section{Acknowledgements}

We gratefully thank the patients for study participation and kindly providing their samples. We highly value the support by the medical doctors and laboratory team of the Department for Gynecology as well as from the colleagues of the Institute for Pathology, both University Hospital Essen.

\section{Funding}

This study was not funded by any agencies in the public, commercial, or not-for-profit sectors.

\section{Availability of data and materials}

The datasets used and/or analysed during this current study are available from the corresponding author $(\mathrm{LK})$ on reasonable request.

\section{Authors' contributions}

LK, SKB and $A B$ conceived and designed the study. LK and $A B$ developed the methodology for microscopic assessment and evaluated the samples. $\mathrm{OH}$ and AKB participated in sample procurement and documented the patients' characteristics. SKB, AB, KWS and RK provided administrative, technical and material support. FDM performed the biostatistical analysis. LK, FDM, SKB and $A B$ interpreted the data results. LK drafted the manuscript and figures/tables with input from SKB, AB, FDM. All authors were involved in reviewing the manuscript and approved the final manuscript. 


\section{Ethics approval and consent to participate}

All patients gave written informed consent for use of their tumor tissue for research purposes. The study was approved by the institutional ethics committee from the University Hospital Essen (16-6915-BO) and fully conforms to the principles outlined in the declaration of Helsinki.

\section{Consent for publication}

Not applicable.

\section{Competing interests}

The authors declare that they have no competing interests.

\section{Publisher's Note}

Springer Nature remains neutral with regard to jurisdictional claims in published maps and institutional affiliations.

\section{Author details}

'Department of Gynecology and Obstetrics, University Hospital Essen, University of Duisburg-Essen, Hufelandstr. 55, 45147 Essen, Germany. ${ }^{2}$ Institute for Pathology, University Hospital Essen, University of

Duisburg-Essen, Hufelandstr. 55, 45147 Essen, Germany.

Received: 7 July 2018 Accepted: 25 January 2019

\section{Published online: 04 February 2019}

\section{References}

1. Siegel RL, Miller KD, Jemal A. Cancer statistics, 2017. CA Cancer J Clin. 2017; 67(1):7-30.

2. Mauri $\mathrm{D}$, Pavlidis N, loannidis JP. Neoadjuvant versus adjuvant systemic treatment in breast cancer: a meta-analysis. J Natl Cancer Inst. 2005;97(3): 188-94.

3. Loibl S, Denkert C, von Minckwitz G. Neoadjuvant treatment of breast cancer--clinical and research perspective. Breast. 2015;24(Suppl 2):S73-7.

4. Bonnefoi H, Litiere S, Piccart M, MacGrogan G, Fumoleau P, Brain E, et al. Pathological complete response after neoadjuvant chemotherapy is an independent predictive factor irrespective of simplified breast cancer intrinsic subtypes: a landmark and two-step approach analyses from the EORTC 10994/BIG 1-00 phase III trial. Ann Oncol. 2014;25(6):1128-36.

5. Gianni L, Pienkowski T, Im YH, Roman L, Tseng LM, Liu MC, et al. Efficacy and safety of neoadjuvant pertuzumab and trastuzumab in women with locally advanced, inflammatory, or early HER2-positive breast cancer (NeoSphere): a randomised multicentre, open-label, phase 2 trial. Lancet Oncol. 2012;13(1):25-32.

6. Sikov WM, Berry DA, Perou CM, Singh B, Cirrincione CT, Tolaney SM, et al. Impact of the addition of carboplatin and/or bevacizumab to neoadjuvant once-perweek paclitaxel followed by dose-dense doxorubicin and cyclophosphamide on pathologic complete response rates in stage II to III triple-negative breast Cancer: CALGB 40603 (Alliance). J Clin Oncol. 2015;33(1):13-21.

7. Banys M, Krawczyk N, Fehm T. The role and clinical relevance of disseminated tumor cells in breast cancer. Cancers (Basel). 2014;6(1):143-52.

8. Hosseini H, Obradovic MM, Hoffmann M, Harper KL, Sosa MS, Werner-Klein M, et al. Early dissemination seeds metastasis in breast cancer. Nature. 2016. https://doi.org/10.1038/nature20785.

9. Braun S, Vogl FD, Naume B, Janni W, Osborne MP, Coombes RC, et al. A pooled analysis of bone marrow micrometastasis in breast cancer. N Engl J Med. 2005;353(8):793-802.

10. Gruber I, Fehm T, Taran FA, Wallwiener M, Hahn M, Wallwiener D, et al. Disseminated tumor cells as a monitoring tool for adjuvant therapy in patients with primary breast cancer. Breast Cancer Res Treat. 2014;144(2):353-60.

11. Hartkopf AD, Taran FA, Wallwiener M, Hagenbeck C, Melcher C, Krawczyk N, et al. The presence and prognostic impact of apoptotic and nonapoptotic disseminated tumor cells in the bone marrow of primary breast cancer patients after neoadjuvant chemotherapy. Breast Cancer Res. 2013:15(5):R94.

12. Janni W, Vogl FD, Wiedswang G, Synnestvedt M, Fehm T, Juckstock J, et al. Persistence of disseminated tumor cells in the bone marrow of breast cancer patients predicts increased risk for relapse--a European pooled analysis. Clin Cancer Res. 2011;17(9):2967-76.

13. Kasimir-Bauer S, Bittner AK, Konig L, Reiter K, Keller T, Kimmig R, et al. Does primary neoadjuvant systemic therapy eradicate minimal residual disease? Analysis of disseminated and circulating tumor cells before and after therapy. Breast Cancer Res. 2016;18(1):20.
14. Tjensvoll K, Oltedal S, Heikkila R, Kvaloy JT, Gilje B, Reuben JM, et al. Persistent tumor cells in bone marrow of non-metastatic breast cancer patients after primary surgery are associated with inferior outcome. BMC Cancer. 2012;12:190.

15. Banys M, Solomayer EF, Gebauer G, Janni W, Krawczyk N, Lueck HJ, et al. Influence of zoledronic acid on disseminated tumor cells in bone marrow and survival: results of a prospective clinical trial. BMC Cancer. 2013;13:480

16. Hoffmann O, Aktas B, Goldnau C, Heubner M, Oberhoff C, Kimmig R, et al. Effect of ibandronate on disseminated tumor cells in the bone marrow of patients with primary breast cancer: a pilot study. Anticancer Res. 2011; 31(10):3623-8

17. Kasimir-Bauer S, Reiter K, Aktas B, Bittner AK, Weber S, Keller T, et al. Different prognostic value of circulating and disseminated tumor cells in primary breast cancer: influence of bisphosphonate intake? Sci Rep. 2016;6:26355.

18. Naume B, Synnestvedt M, Falk RS, Wiedswang G, Weyde K, Risberg T, et al. Clinical outcome with correlation to disseminated tumor cell (DTC) status after DTC-guided secondary adjuvant treatment with docetaxel in early breast cancer. J Clin Oncol. 2014;32(34):3848-57.

19. Rack B, Juckstock J, Genss EM, Schoberth A, Schindlbeck C, Strobl B, et al. Effect of zoledronate on persisting isolated tumour cells in patients with early breast cancer. Anticancer Res. 2010;30(5):1807-13.

20. Solomayer E, Gebauer G, Hirnle P, Janni W, Lück H, Becker S, et al. Influence of zoledronic acid on disseminated tumor cells (DTC) in primary breast cancer patients. Cancer Res. 2009;69(2 Supplement):2048.

21. Gilbert CA, Slingerland JM. Cytokines, obesity, and cancer: new insights on mechanisms linking obesity to cancer risk and progression. Annu Rev Med. 2013;64:45-57.

22. O'Callaghan DS, O'Donnell D, O'Connell F, O'Byrne KJ. The role of inflammation in the pathogenesis of non-small cell lung cancer. J Thoracic Oncol. 2010;5(12):2024-36.

23. Salgado R, Denkert C, Demaria S, Sirtaine N, Klauschen F, Pruneri G, et al. The evaluation of tumor-infiltrating lymphocytes (TILs) in breast cancer: recommendations by an international TILs working group 2014. Ann Oncol. 2015;26(2):259-71

24. Fridman WH, Pages F, Sautes-Fridman C, Galon J. The immune contexture in human tumours: impact on clinical outcome. Nat Rev Cancer. 2012;12(4):298-306.

25. Ravelli A, Roviello G, Cretella D, Cavazzoni A, Biondi A, Cappelletti MR, et al. Tumor-infiltrating lymphocytes and breast cancer: beyond the prognostic and predictive utility. Tumour Biol. 2017;39(4):1010428317695023.

26. Ingold Heppner B, Untch M, Denkert C, Pfitzner BM, Lederer B, Schmitt W, et al. Tumor-infiltrating lymphocytes: a predictive and prognostic biomarker in neoadjuvant-treated HER2-positive breast Cancer. Clin Cancer Res. 2016; 22(23):5747-54.

27. Loi S, Michiels S, Salgado R, Sirtaine N, Jose V, Fumagalli D, et al. Tumor infiltrating lymphocytes are prognostic in triple negative breast cancer and predictive for trastuzumab benefit in early breast cancer: results from the FinHER trial. Ann Oncol. 2014;25(8):1544-50.

28. Denkert C, Loibl S, Noske A, Roller M, Muller BM, Komor M, et al. Tumorassociated lymphocytes as an independent predictor of response to neoadjuvant chemotherapy in breast cancer. J Clin Oncol. 2010;28(1):105-13.

29. Denkert C, von Minckwitz G, Darb-Esfahani S, Lederer B, Heppner BI, Weber $K E$, et al. Tumour-infiltrating lymphocytes and prognosis in different subtypes of breast cancer: a pooled analysis of 3771 patients treated with neoadjuvant therapy. Lancet Oncol. 2018;19(1):40-50.

30. Gobert M, Treilleux I, Bendriss-Vermare N, Bachelot T, Goddard-Leon S, Arfi $\checkmark$, et al. Regulatory T cells recruited through CCL22/CCR4 are selectively activated in lymphoid infiltrates surrounding primary breast tumors and lead to an adverse clinical outcome. Cancer Res. 2009;69(5):2000-9.

31. Gu-Trantien C, Loi S, Garaud S, Equeter C, Libin M, de Wind A, et al. CD4(+) follicular helper T cell infiltration predicts breast cancer survival. J Clin Invest. 2013;123(7):2873-92.

32. Liu S, Foulkes WD, Leung S, Gao D, Lau S, Kos Z, et al. Prognostic significance of FOXP3+ tumor-infiltrating lymphocytes in breast cancer depends on estrogen receptor and human epidermal growth factor receptor-2 expression status and concurrent cytotoxic T-cell infiltration. Breast Cancer Res. 2014;16(5):432

33. Bates GJ, Fox SB, Han C, Leek RD, Garcia JF, Harris AL, et al. Quantification of regulatory $T$ cells enables the identification of high-risk breast cancer patients and those at risk of late relapse. J Clin Oncol. 2006;24(34):5373-80.

34. West NR, Kost SE, Martin SD, Milne K, Deleeuw RJ, Nelson BH, et al. Tumourinfiltrating FOXP3(+) lymphocytes are associated with cytotoxic immune 
responses and good clinical outcome in oestrogen receptor-negative breast cancer. Br J Cancer. 2013;108(1):155-62.

35. Mahmoud SM, Paish EC, Powe DG, Macmillan RD, Grainge MJ, Lee AH, et al. Tumor-infiltrating CD8+ lymphocytes predict clinical outcome in breast cancer. J Clin Oncol. 2011;29(15):1949-55.

36. Nelson $\mathrm{BH}$. CD20+ B cells: the other tumor-infiltrating lymphocytes. J Immunol. 2010;185(9):4977-82.

37. Mukhtar RA, Nseyo O, Campbell MJ, Esserman LJ. Tumor-associated macrophages in breast cancer as potential biomarkers for new treatments and diagnostics. Expert Rev Mol Diagn. 2011;11(1):91-100.

38. DeNardo DG, Brennan DJ, Rexhepaj E, Ruffell B, Shiao SL, Madden SF, et al. Leukocyte complexity predicts breast cancer survival and functionally regulates response to chemotherapy. Cancer Discov. 2011;1(1):54-67.

39. Tsutsui S, Yasuda K, Suzuki K, Tahara K, Higashi H, Era S. Macrophage infiltration and its prognostic implications in breast cancer: the relationship with VEGF expression and microvessel density. Oncol Rep. 2005;14(2):425-31.

40. Campbell MJ, Tonlaar NY, Garwood ER, Huo D, Moore DH, Khramtsov Al, et al. Proliferating macrophages associated with high grade, hormone receptor negative breast cancer and poor clinical outcome. Breast Cancer Res Treat. 2011;128(3):703-11.

41. Dirat B, Bochet L, Dabek M, Daviaud D, Dauvillier S, Majed B, et al. Cancerassociated adipocytes exhibit an activated phenotype and contribute to breast cancer invasion. Cancer Res. 2011;71(7):2455-65.

42. Motrescu ER, Rio M-C. Cancer cells, adipocytes and matrix metalloproteinase 11: a vicious tumor progression cycle. Biol Chem. 2008;389(8):1037-41.

43. Galon J, Costes A, Sanchez-Cabo F, Kirilovsky A, Mlecnik B, Lagorce-Pages C, et al. Type, density, and location of immune cells within human colorectal tumors predict clinical outcome. Science. 2006;313(5795):1960-4.

44. von Minckwitz G, Untch M, Blohmer JU, Costa SD, Eidtmann H, Fasching PA, et al. Definition and impact of pathologic complete response on prognosis after neoadjuvant chemotherapy in various intrinsic breast cancer subtypes. J Clin Oncol. 2012;30(15):1796-804.

45. Tavassoli F, Devilee P. World Health Organization classification of Tumours: pathology and genetics of Tumours of the breast and female genital organs. Lyon: IARC Press; 2003.

46. Sobin LH, Wittekind C. International Union against Cancer (UICC). TNM classification of malignant Tumours. 6th ed. New York: Wiley; 2002.

47. Elston CW, Ellis IO. Pathological prognostic factors in breast cancer. I. The value of histological grade in breast cancer: experience from a large study with long-term follow-up. Histopathology. 1991;19(5):403-10.

48. Sinn HP, Schmid H, Junkermann H, Huober J, Leppien G, Kaufmann M, et al. Histologic regression of breast cancer after primary (neoadjuvant) chemotherapy. Geburtshilfe Frauenheilkd. 1994;54(10):552-8.

49. Fehm T, Braun S, Muller V, Janni W, Gebauer G, Marth C, et al. A concept for the standardized detection of disseminated tumor cells in bone marrow from patients with primary breast cancer and its clinical implementation. Cancer. 2006;107(5):885-92.

50. Bryne M, Boysen M, Alfsen CG, Abeler VM, Sudbo J, Nesland JM, et al. The invasive front of carcinomas. The most important area for tumour prognosis? Anticancer Res. 1998;18(6b):4757-64.

51. Hendry S, Salgado R, Gevaert T, Russell PA, John T, Thapa B, et al. Assessing tumor-infiltrating lymphocytes in solid tumors: a practical review for pathologists and proposal for a standardized method from the international Immunooncology biomarkers working group: part 1: assessing the host immune response, TILs in invasive breast carcinoma and ductal carcinoma in situ, metastatic tumor deposits and areas for further research. Adv Anat Pathol. 2017;24(5):235-51.

52. Salgado R, Denkert C, Campbell C, Savas P, Nuciforo P, Aura C, et al. Tumorinfiltrating lymphocytes and associations with pathological complete response and event-free survival in HER2-positive early-stage breast Cancer treated with Lapatinib and Trastuzumab: a secondary analysis of the NeoALTTO trial. JAMA Oncol. 2015;1(4):448-54.

53. Galon J, Mlecnik B, Bindea G, Angell HK, Berger A, Lagorce C, et al. Towards the introduction of the 'Immunoscore' in the classification of malignant tumours. J Pathol. 2014;232(2):199-209.

54. Garcia-Martinez E, Gil GL, Benito AC, Gonzalez-Billalabeitia E, Conesa MA, Garcia Garcia T, et al. Tumor-infiltrating immune cell profiles and their change after neoadjuvant chemotherapy predict response and prognosis of breast cancer. Breast Cancer Res. 2014;16(6):488.

55. Schweiger T, Berghoff AS, Glogner C, Glueck O, Rajky O, Traxler D, et al. Tumor-infiltrating lymphocyte subsets and tertiary lymphoid structures in pulmonary metastases from colorectal cancer. Clin Exp Metastasis. 2016; 33(7):727-39.

56. Schneble E, Jinga DC, Peoples G. Breast Cancer immunotherapy. Maedica. 2015;10(2):185-91.

57. Leek RD, Lewis CE, Whitehouse R, Greenall M, Clarke J, Harris AL. Association of macrophage infiltration with angiogenesis and prognosis in invasive breast carcinoma. Cancer Res. 1996;56(20):4625-9.

58. Mani NL, Schalper KA, Hatzis C, Saglam O, Tavassoli F, Butler M, et al. Quantitative assessment of the spatial heterogeneity of tumor-infiltrating lymphocytes in breast cancer. Breast Cancer Res. 2016;18(1):78.

59. Halama N, Michel S, Kloor M, Zoernig I, Benner A, Spille A, et al. Localization and density of immune cells in the invasive margin of human colorectal cancer liver metastases are prognostic for response to chemotherapy. Cancer Res. 2011;71(17):5670-7.

60. Bryne M. Is the invasive front of an oral carcinoma the most important area for prognostication? Oral Dis. 1998;4(2):70-7.

61. Eiro N, Pidal I, Fernandez-Garcia B, Junquera S, Lamelas ML, del Casar JM, et al. Impact of CD68/(CD3+CD20) ratio at the invasive front of primary tumors on distant metastasis development in breast cancer. PLoS One. 2012;7(12):e52796.

62. Roncati L, Barbolini G, Piacentini F, Piscioli F, Pusiol T, Maiorana A. Prognostic factors for breast Cancer: an Immunomorphological update. Pathol Oncol Res. 2016;22(3):449-52.

63. Zitvogel L, Kepp O, Kroemer G. Immune parameters affecting the efficacy of chemotherapeutic regimens. Nat Rev Clin Oncol. 2011;8(3):151-60.

64. Loi S, Sirtaine N, Piette F, Salgado R, Viale G, Van Eenoo F, et al. Prognostic and predictive value of tumor-infiltrating lymphocytes in a phase III randomized adjuvant breast cancer trial in node-positive breast cancer comparing the addition of docetaxel to doxorubicin with doxorubicinbased chemotherapy: BIG 02-98. J Clin Oncol. 2013;31(7):860-7.

65. Yu X, Zhang Z, Wang Z, Wu P, Qiu F, Huang J. Prognostic and predictive value of tumor-infiltrating lymphocytes in breast cancer: a systematic review and meta-analysis. Clin Transl Oncol. 2016;18(5):497-506.

66. Huszno J, Nozynska EZ, Lange D, Kolosza Z, Nowara E. The association of tumor lymphocyte infiltration with clinicopathological factors and survival in breast cancer. Pol J Pathol. 2017;68(1):26-32.

67. Andre F, Dieci MV, Dubsky P, Sotiriou C, Curigliano G, Denkert C, et al. Molecular pathways: involvement of immune pathways in the therapeutic response and outcome in breast cancer. Clin Cancer Res. 2013;19(1):28-33.

68. Ono M, Tsuda H, Shimizu C, Yamamoto S, Shibata T, Yamamoto H, et al. Tumor-infiltrating lymphocytes are correlated with response to neoadjuvant chemotherapy in triple-negative breast cancer. Breast Cancer Res Treat. 2012;132(3):793-805.

69. Issa-Nummer Y, Darb-Esfahani S, Loibl S, Kunz G, Nekljudova V, Schrader I, et al. Prospective validation of immunological infiltrate for prediction of response to neoadjuvant chemotherapy in HER2-negative breast cancer-a substudy of the neoadjuvant GeparQuinto trial. PLoS One. 2013;8(12):e79775.

70. Denkert C, von Minckwitz G, Brase JC, Sinn BV, Gade S, Kronenwett R, et al. Tumor-infiltrating lymphocytes and response to neoadjuvant chemotherapy with or without carboplatin in human epidermal growth factor receptor 2positive and triple-negative primary breast cancers. J Clin Oncol. 2015;33(9): 983-91.

71. Denkert C, Wienert S, Poterie A, Loibl S, Budczies J, Badve S, et al. Standardized evaluation of tumor-infiltrating lymphocytes in breast cancer: results of the ring studies of the international immuno-oncology biomarker working group. Mod Pathol. 2016;29(10):1155-64.

72. Swisher SK, Wu Y, Castaneda CA, Lyons GR, Yang F, Tapia C, et al. Interobserver agreement between pathologists assessing tumor-infiltrating lymphocytes (TILs) in breast Cancer using methodology proposed by the international TILs working group. Ann Surg Oncol. 2016;23(7):2242-8.

73. DeNardo DG, Barreto JB, Andreu P, Vasquez L, Tawfik D, Kolhatkar N, et al. CD4(+ ) T cells regulate pulmonary metastasis of mammary carcinomas by enhancing protumor properties of macrophages. Cancer Cell. 2009;16(2):91-102.

74. Du Y, Chen X, Lin XQ, Wu W, Huang ZM. Tumor-derived CD4+CD25+ Tregs inhibit the maturation and antigen-presenting function of dendritic cells. Asian Pac J Cancer Prev. 2015;16(7):2665-9.

75. McNally A, Hill GR, Sparwasser T, Thomas R, Steptoe RJ. CD4+CD25+ regulatory $T$ cells control CD8+ T-cell effector differentiation by modulating IL-2 homeostasis. Proc Natl Acad Sci U S A. 2011;108(18):7529-34.

76. Chen ML, Pittet MJ, Gorelik L, Flavell RA, Weissleder R, von Boehmer H, et al. Regulatory T cells suppress tumor-specific CD8 T cell cytotoxicity through TGF-beta signals in vivo. Proc Natl Acad Sci U S A. 2005;102(2):419-24. 
77. Monteiro AC, Leal AC, Goncalves-Silva T, Mercadante AC, Kestelman F, Chaves SB, et al. T cells induce pre-metastatic osteolytic disease and help bone metastases establishment in a mouse model of metastatic breast cancer. PLoS One. 2013;8(7):e68171.

78. Balic M, Lin H, Young L, Hawes D, Giuliano A, McNamara G, et al. Most early disseminated cancer cells detected in bone marrow of breast cancer patients have a putative breast cancer stem cell phenotype. Clin Cancer Res. 2006;12(19):5615-21.

79. Reuben JM, Lee BN, Gao H, Cohen EN, Mego M, Giordano A, et al. Primary breast cancer patients with high risk clinicopathologic features have high percentages of bone marrow epithelial cells with ALDH activity and CD44(+ )CD24lo cancer stem cell phenotype. Eur J Cancer. 2011;47(10):1527-36.

80. Falck AK, Bendahl PO, Ingvar C, Isola J, Jonsson PE, Lindblom P, et al. Analysis of and prognostic information from disseminated tumour cells in bone marrow in primary breast cancer: a prospective observational study. BMC Cancer. 2012;12:403.

81. Axelrod HD, Pienta KJ, Valkenburg KC. Optimization of immunofluorescent detection of bone marrow disseminated tumor cells. Biol Proced Online. 2018:20:13.

82. Pantel K, Hayes DF. Disseminated breast tumour cells: biological and clinical meaning. Nat Rev Clin Oncol. 2018;15(3):129-31.

83. Masoud V, Pagès G. Targeted therapies in breast cancer: new challenges to fight against resistance. World J Clin Oncol. 2017;8(2):120-34.

84. Persson J, Beyer I, Yumul R, Li Z, Kiem HP, Roffler S, et al. Immuno-therapy with anti-CTLA4 antibodies in tolerized and non-tolerized mouse tumor models. PLoS One. 2011:6(7):e22303.

85. Vonderheide RH, LoRusso PM, Khalil M, Gartner EM, Khaira D, Soulieres D, et al. Tremelimumab in combination with Exemestane in patients with advanced breast Cancer and treatment-associated modulation of inducible Costimulator expression on patient T cells. Clin Cancer Res. 2010;16(13):3485-94.

86. Stagg J, Loi S, Divisekera U, Ngiow SF, Duret H, Yagita H, et al. Anti-ErbB-2 mAb therapy requires type I and II interferons and synergizes with anti-PD1 or anti-CD137 mAb therapy. Proc Natl Acad Sci. 2011;108(17):7142-7.

87. Schmid P, Adams S, Rugo HS, Schneeweiss A, Barrios CH, Iwata H, et al. Atezolizumab and nab-paclitaxel in advanced triple-negative breast Cancer. N Engl J Med. 2018;379(22):2108-21.

88. Hammond ME, Hayes DF, Dowsett M, Allred DC, Hagerty KL, Badve S, et al. American Society of Clinical Oncology/college of American pathologists guideline recommendations for immunohistochemical testing of estrogen and progesterone receptors in breast cancer. J Clin Oncol. 2010;28(16):2784-95.

89. Wolff AC, Hammond ME, Schwartz JN, Hagerty KL, Allred DC, Cote RJ, et al. American Society of Clinical Oncology/College of American Pathologists guideline recommendations for human epidermal growth factor receptor 2 testing in breast cancer. Arch Pathol Lab Med. 2007;131(1):18-43.

Ready to submit your research? Choose BMC and benefit from:

- fast, convenient online submission

- thorough peer review by experienced researchers in your field

- rapid publication on acceptance

- support for research data, including large and complex data types

- gold Open Access which fosters wider collaboration and increased citations

- maximum visibility for your research: over $100 \mathrm{M}$ website views per year

At BMC, research is always in progress.

Learn more biomedcentral.com/submissions 